\title{
Manganese Oxide/Mesoporous Carbon Spherical Composite:Study on Its Enhanced Catalytic and Electrochemical Performance
}

\author{
Zuosong Sun \\ Research Institute of Applied Catalysis, School of \\ Chemical and Environmental Engineering, Shanghai \\ Institute of Technology \\ Shanghai, P. R.China \\ 13162591529@163.com
}

Shaodian Shen

Research Institute of Applied Catalysis, School of Chemical and Environmental Engineering, Shanghai Institute of Technology Shanghai, P. R.China mingtiansit@163.com

\author{
Dongsen Mao \\ Research Institute of Applied Catalysis, School of \\ Chemical and Environmental Engineering, Shanghai \\ Institute of Technology \\ Shanghai, P. R.China \\ dsmao@sit.edu.cn \\ Guanzhong Lu \\ Research Institute of Applied Catalysis, School of \\ Chemical and Environmental Engineering, Shanghai \\ Institute of Technology \\ Shanghai, P. R.China \\ gzhlu@ ecust.edu.cn
}

\begin{abstract}
Manganese oxide/mesoporous carbon ( $\left.\mathrm{MnO}_{2} / \mathrm{MCs}\right)$ spherical composites were prepared by hydrothermal method. The resorcinol and potassium permanganate were used as carbon source and manganese source,respectively. The morphology and pore character of the carbon materials were investigated by scanning electron microscopy(SEM), $X$ ray diffraction(XRD), and nitrogen adsorption-desorption. The measurements show the sample with the corresponding spherical morphology and mesoporous structure. By controlling the concentration of potassium permanganate, various amount of manganese in carbon/manganese oxide can be obtained. The composite was employed as the support of Au catalyst for $\mathrm{CO}$ oxidation. Different amount of gold has been deposited on the as-synthesized carbon sphere/manganese oxide, and the activity and stability of $\mathrm{Au}$ catalyst after sintered at $300^{\circ} \mathrm{C}$ has been tested. The $8 \% \mathrm{Au} / \mathrm{MnO} / \mathrm{MCs}-46$ catalyst had obvious deactivation on stream after $65 \mathrm{~h}$ reaction time at the reaction temperature of $185^{\circ} \mathrm{C}$. Meanwhile, the sample further used as the supercapacitor electrode materials for electrochemical performance test. The specific capacitance of the $\mathrm{MnO}_{2} / \mathrm{MCs}-30$ electrode is as high as $275 \mathrm{Fg}^{-1}$ at $0.5 \mathrm{Ag}^{-1}$.
\end{abstract}

Keywords-sphere; template; manganese oxide; CO oxidation; electrochemistry;

\section{INTRODUCTION}

In the past decade, the global warming and fossil energy sharply reduced has led to lots of efforts in developing low cost, safe and environmentally friendly energy sources[1-4]. Supercapacitors has received considerable attention, owning to their high power density, long cycle life and fast charging-discharging rates[5-7]. Carbon-based materials, including conducting polymers[8,9] and transition metal oxides have been widely used as electrode materials for supercapacitors. $\mathrm{MnO}_{2}$ also has been study on supercapactor and $\mathrm{CO}$ oxidation. Owning to its poor electrical conductivity, $\mathrm{MnO}_{2}$ was incorporated into conductive matrixes( such as carbon material) to overcome drawback[10,11].

In this paper, we report $\mathrm{MnO}_{2} / \mathrm{MC}$ spherical composite through a facile method to synthesis. Using the sample as the support of catalyst which is used for $\mathrm{CO}$ oxidation and using nickel foam with deposited sample as the working electrode which is used for Electrochemical measurements.

\section{EXPERIMENTAL SECTION}

\subsection{Materials}

Ammonia aqueous,ethanol,potassium permanganate, hexadecyl trimethylammoniumchloride(CTAC), tetraethyl orthosilicate(TEOS), were purchased from shanghai Titan Co. All chemicals were used as received without any further purification.

\subsection{Synthesis}

Synthesis of manganese oxide/mesoporous carbon spherical composite: For the typical synthesis of the mesoporous carbon spheres, CTAC $(0.25 \mathrm{~g})$ and ammonia aqueous solution $\left(\mathrm{NH}_{4} \mathrm{OH}, \quad 0.4 \mathrm{~g}, 25 \mathrm{wt} \%\right)$ were first dissolved in a mixture of ethanol $(6 \mathrm{~g})$ and water $(20 \mathrm{~g})$ which were stirred for $30 \mathrm{~min}$. Subsequently resorcinol $(0.2 \mathrm{~g})$ and tetraethyl orthosilicate(TEOS) $(0.4 \mathrm{~g})$ and formaldehyde solution $(0.44 \mathrm{~g})$ were added to the reaction solution and stirred for $24 \mathrm{~h}$ at $30^{\circ} \mathrm{C}$. The solid product was recovered by centrifugation and air-dried at $80^{\circ} \mathrm{C}$ over night. The carbonization was carried out in a tubular furnace under $\mathrm{N}_{2}$ atmosphere at $300^{\circ} \mathrm{C}$ for $2 \mathrm{~h}$ and at $600^{\circ} \mathrm{C}$ with a ramp rate of $1^{\circ} \mathrm{Cmin}^{-1}$ to make sure carbon spheres precursors completely converted subsequently. The carbon spheres and $\mathrm{KMnO}_{4}(30 \mathrm{mg}, 50 \mathrm{mg}, 70 \mathrm{mg}$, $100 \mathrm{mg}$ ) was further dispersed in water and stirred for $2 \mathrm{~h}$. 
The mixture was placed in a $40 \mathrm{ml}$ Teflon-sealed autoclave and maintained at $180^{\circ} \mathrm{C}$ for $40 \mathrm{~min}$. The product were washed with deionized water and ethanol, followed by drying at $60^{\circ} \mathrm{C}$ for $12 \mathrm{~h}$. The silica template was removed by $2 \mathrm{M} \mathrm{NaOH}$ solution at $80^{\circ} \mathrm{C}$ for $24 \mathrm{~h}$. Then samples were washed with deionized water and ethanol, followed by drying at $60^{\circ} \mathrm{C}$ for $12 \mathrm{~h}$. The content of $\mathrm{MnO}_{2}$ in the three $\mathrm{MnO}_{2} / \mathrm{MCs}$ composites was estimated to be $25 \%$, $30 \%, 35 \%$ and $46 \%$ by TG test, respectively. And the composites were then denoted as $\mathrm{MnO}_{2} / \mathrm{MCs}-25$, $\mathrm{MnO}_{2} / \mathrm{MCs}-30, \mathrm{MnO}_{2} / \mathrm{MCs}-35$ and $\mathrm{MnO}_{2} / \mathrm{MCs}-46$, respectively.

To load gold nanoparticles, $0.5 \mathrm{~g}$ of $\mathrm{MnO}_{2} / \mathrm{MCs}-46$ was dissolved into $30 \mathrm{~g}$ of water and $10 \mathrm{ml}, 50 \mathrm{ml}$ and $80 \mathrm{ml}$ of $0.243 \mathrm{mmol} / \mathrm{L} \mathrm{HAuCl} \mathrm{H}_{4} \cdot 3 \mathrm{H}_{2} \mathrm{O}$ was also dropped into the solution. The $\mathrm{pH}$ value was adjusted to 7 using $1.0 \mathrm{M}$ $\mathrm{NaOH}$, and the solution was heated to $75^{\circ} \mathrm{C}$. The mixture was stirred for $2 \mathrm{~h}$, after which the precipitates were separated by centrifugation and washed four times with water. The product was dried at $40^{\circ} \mathrm{Cand}$ was calcined at $300^{\circ} \mathrm{C}$ for $2 \mathrm{~h}$ to obtain the as-synthesized catalyst. The catalyst were then denoted as $1 \% \mathrm{Au} / \mathrm{MnO}_{2} / \mathrm{MCs}-46$, $5 \% \mathrm{MnO}_{2} / \mathrm{MCs}-46,8 \% \mathrm{MnO}_{2} / \mathrm{MCs}-46$, respectively.

\subsection{Electrochemical Measurements}

Electrochemical measurements were conducted on a computer-controlled potentiostat (CHI 660E,CH Instrument, USA) with a three-electrode electrochemical cell. The standard three-electrode electrochemical cell was fabricated using nickel foam with deposited sample as the working electrode, platinum wire as the counter electrode, and $\mathrm{Hg} / \mathrm{HgO}$ as the reference electrode. The fabrication of working electrode, a mixture containing active materials (80wt\%), acetylene black (10wt\%), and polytetrfluoroethylene (PTFE; $10 \mathrm{wt} \%$ ) were well mixed to form a homogeneous slurry. The slurry was then pressed onto a nickel foam with an area of $1 \mathrm{~cm}^{2}$ and followed by drying at $120^{\circ} \mathrm{C}$ for $10 \mathrm{~h}$. The mass loading of the active material was about 5mg. All the electrochemical measurements were carried out at $25^{\circ} \mathrm{C}$ using a $6 \mathrm{M} \mathrm{KOH}$ electrolyte. The potentials for electrochemical measurements are reported relative to a $\mathrm{Hg} / \mathrm{HgO}$ reference electrode and the potential window for cycling was confined between $-1.1 \mathrm{~V}$ and $-0.1 \mathrm{~V}$. The gravimetric specific capacitance $\mathrm{Cg}$ was calculated according to the following equation using the discharge portion of the charge-discharge curves:

$$
\mathrm{Cg}=\mathrm{I} \Delta \mathrm{t} / \mathrm{m} \Delta \mathrm{V}=\mathrm{I} / \mathrm{mK}
$$

where $\mathrm{I}, \Delta \mathrm{t}, \Delta \mathrm{V}, \mathrm{m}$, and $\mathrm{K}$ are the applied current, discharge time, voltage change, the mass of active material, and the slope of the discharge curve, respectively.

\subsection{Characterization}

Scanning electron microscopy (SEM) images were taken by a Hitachi S3400 scanning electron microscope. $\mathrm{X}$-ray scattering (XRD) measurements were taken on a Panalytical X'Pert Diffractometer using $\mathrm{Cu}$ Ka radiation (40 kV, $40 \mathrm{~mA})$. Nitrogen sorption isotherms were measured at $77 \mathrm{~K}$ with a Micromeritics ASAP 2020 system. Before measurements, the samples were degassed in a vacuum at $200^{\circ} \mathrm{C}$ for at least $10 \mathrm{~h}$. The BrunauerEmmett-Teller (BET) method was utilized to calculate the specific surface areas. By using the Barrett-JoynerHalenda(BJH) model, the pore volumes and pore size distributions were derived from the adsorption branches of isotherms, and the total pore volumes $(\mathrm{V})$ were estimated from the adsorbed amount at a relative pressure $\mathrm{P} / \mathrm{P}_{0}$ of 0.995 .

\section{RESULTS AND DISCUSSION}

The SEM image of mesoporous carbon spheres (Figure 1a.) was found that the morpology is spherical and partical size is about $300 \mathrm{~nm}$. Figure $1 \mathrm{~b}$ shows the morphology of $\mathrm{MnO}_{2} / \mathrm{MC}$ spherical composite is also spherical and partical size is about $500 \mathrm{~nm} . \mathrm{MnO}_{2} / \mathrm{MC}$ spherical composite with bigger partical size illustrates $\mathrm{MnO}_{2}$ doped on the surface of MCs .
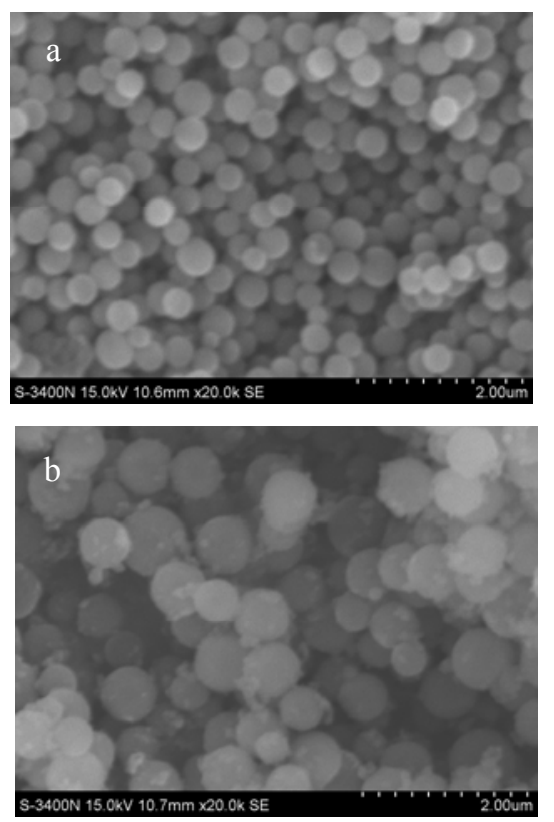

Figure 1. SEM images of (a) mesoporus carbon sphere (MCs)without $\mathrm{MnO}_{2}$ and (b) $\mathrm{MnO}_{2} /$ mesoprous carbon spherical composite $\left(\mathrm{MnO}_{2} / \mathrm{MCs}\right)$.

Wide angle XRD patterns of $\mathrm{MnO}_{2} / \mathrm{MCs}$ and $\mathrm{Au} / \mathrm{MnO}_{2} / \mathrm{MCs}$ are shown in Figure 2. Seen from the Figure 2, there are typical diffraction peak of $\mathrm{MnO}_{2}(2 \theta=$ $12.38^{\circ}, 24.90^{\circ}, 35.61^{\circ}, 36.97^{\circ}, 41.90^{\circ}$, JCPDS 43-1456) corresponding to its Birnessite structure. $\mathrm{Au} / \mathrm{MnO}_{2} / \mathrm{MC}$ spherical composite has typical diffraction peak of $\operatorname{Au}\left(2 \theta=38.19^{\circ}, 44.45^{\circ}, 64.59^{\circ}, 77.69^{\circ}\right.$, JCPDS 04-0784) and the diffraction peak of $\mathrm{Mn}_{\mathrm{X}} \mathrm{O}$ which obtained by $\mathrm{MnO}_{2}$ and $\mathrm{MCs}$ taking place. 


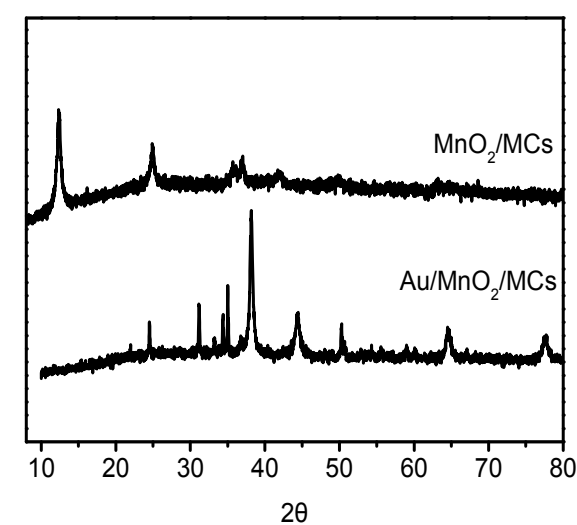

Figure 2. XRD pattern of $\mathrm{MnO}_{2} / \mathrm{C}$ and $\mathrm{Au} / \mathrm{MnO}_{2} / \mathrm{C}$
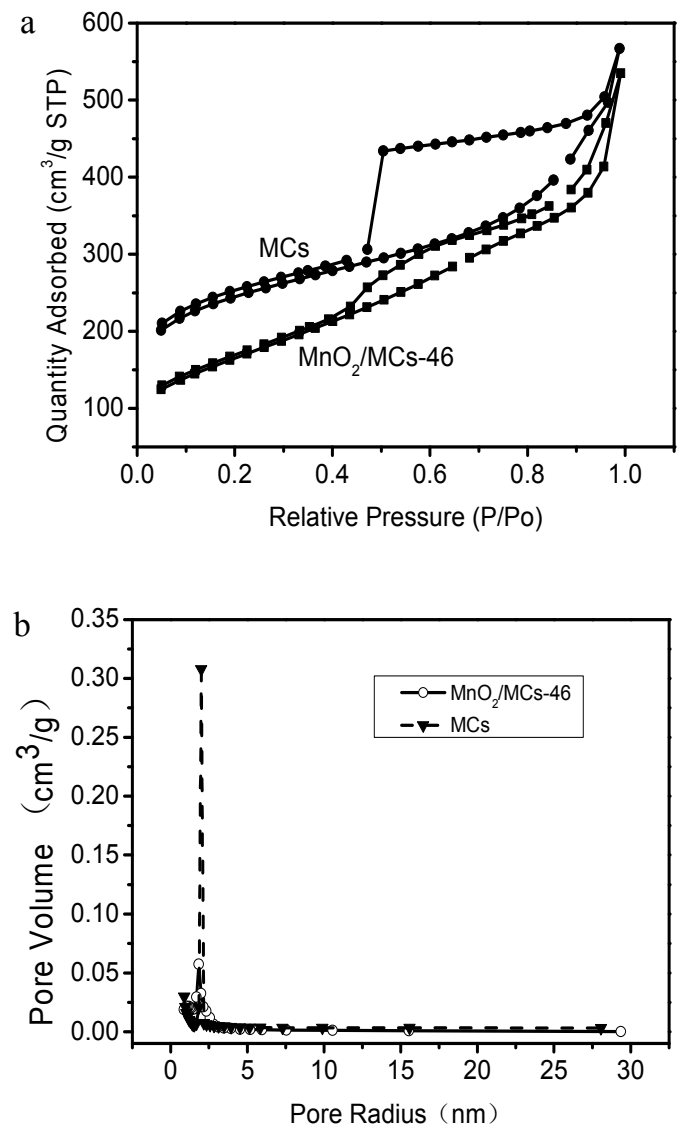

Figure 3. Nitrogen adsorption-desorption isotherms of (a) $\mathrm{MnO}_{2} / \mathrm{MCs}-46$ and $\mathrm{MCs}$ and $\mathrm{BJH}$ pore size distribution of (b) $\mathrm{MnO}_{2} / \mathrm{MCs}-46$ and $\mathrm{MCs}$

Figure 3 gives the $\mathrm{N}_{2}$ sorption isotherms (Figure 3a) and $\mathrm{BJH}$ pore size distribution plots (Figure $3 \mathrm{~b}$ ) of $\mathrm{MnO}_{2} / \mathrm{MCs}-46$ and $\mathrm{MCs}$, the isotherms exhibit the same type IV adsorption behavior. The interpolation of pore size distribution reveals a uniform pore size. The surface area of $\mathrm{MCs}$ and $\mathrm{MnO}_{2} / \mathrm{MCs}-46$ is $806 \mathrm{~m}^{2} \mathrm{~g}^{-1}$ and $588 \mathrm{~m}^{2} \mathrm{~g}^{-1}$, pore volume is $0.877 \mathrm{~cm}^{3} \mathrm{~g}^{-1}$ and $0.827 \mathrm{~cm}^{3} \mathrm{~g}^{-1}$ from the BET method and BJH method. The BJH pore size of MCs and $\mathrm{MnO}_{2} / \mathrm{MCs}-46$ is $4.3 \mathrm{~nm}$ and $5.6 \mathrm{~nm}$, respectively. The surface area and pore volume of $\mathrm{MnO}_{2} / \mathrm{MCs}-46$ reduced can be attributed to the deposition of $\mathrm{MnO}_{2}$ nanoparticles.
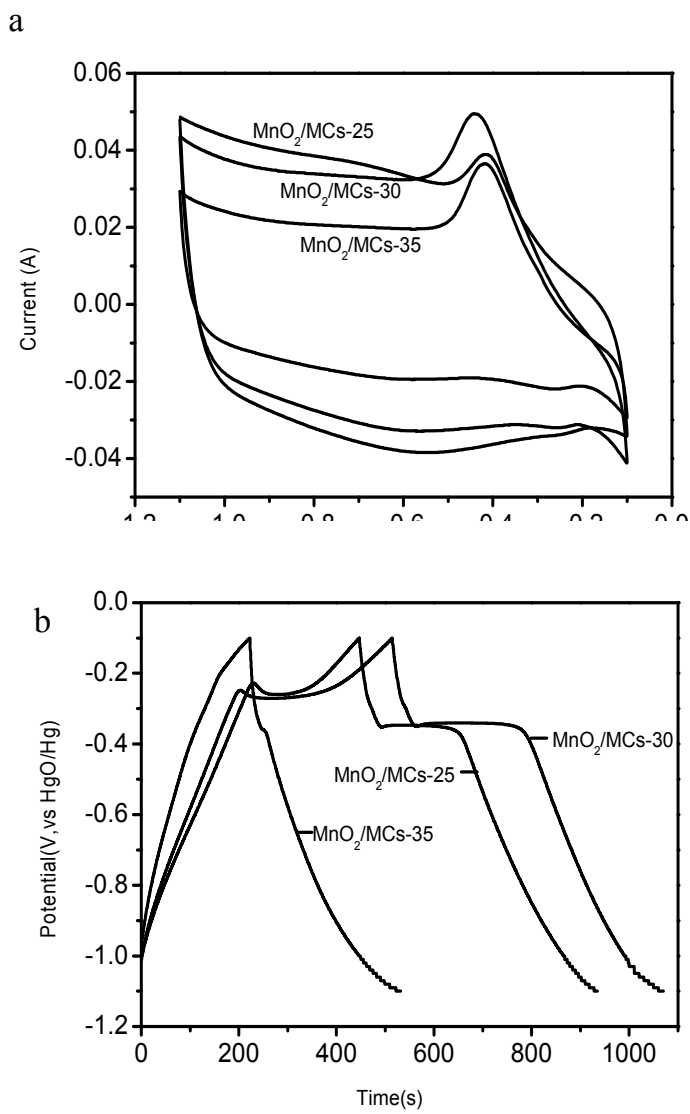

Figure 4. Electrochemical performance of the supercapacitors: (a) CV curves of $\mathrm{MnO}_{2} / \mathrm{MCs}-25, \mathrm{MnO}_{2} / \mathrm{MCs}-30, \mathrm{MnO}_{2} / \mathrm{MCs}-35$ at the scan rate of $50 \mathrm{mV} / \mathrm{s}$ and (b) charge-discharge curves of $\mathrm{MnO}_{2} / \mathrm{MCs}$ $25, \mathrm{MnO}_{2} / \mathrm{MCs}-30, \mathrm{MnO}_{2} / \mathrm{MCs}-35$ at a current density of $0.5 \mathrm{~A} / \mathrm{g}$.

Figure $4 \mathrm{a}$ exhibits the cyclic voltammograms of $\mathrm{MnO}_{2} / \mathrm{MCs}-25, \mathrm{MnO}_{2} / \mathrm{MCs}-30, \mathrm{MnO}_{2} / \mathrm{MCs}-35$ electrodes at a scan rate of $50 \mathrm{mVs}^{-1}$ in $6 \mathrm{M} \mathrm{KOH}$ electrolyte. $\mathrm{MnO}_{2} / \mathrm{MCs}-25, \mathrm{MnO}_{2} / \mathrm{MCs}-30, \mathrm{MnO}_{2} / \mathrm{MCs}-35$ electrodes show the absence of oxidation and reduction peaks ranging from -1.1 to $-0.1 \mathrm{~V}$, suggests that the supercapacitor is charged-discharged at a pseudo constant rate over the complete voltammetric cycles. Among $\mathrm{MnO}_{2} / \mathrm{MCs}$ electrodes, $\mathrm{MnO}_{2} / \mathrm{MCs}-30$ with the highest integrated area in the cyclic voltammograms shows the electrochemical capacitance is largest. Figure $4 \mathrm{~b}$ shows the galvanostatic charge-discharge curves of $\mathrm{MnO}_{2} / \mathrm{MCs}-$ $25, \mathrm{MnO}_{2} / \mathrm{MCs}-30, \mathrm{MnO}_{2} / \mathrm{MCs}-35$ electrodes at a loading current density of $0.5 \mathrm{Ag}^{-1}$ in $6 \mathrm{M} \mathrm{KOH}$ solution. These curves are symmetric, suggesting good reversibility. The specific capacitance of the $\mathrm{MnO}_{2} / \mathrm{MCs}-30$ electrode is as high as $275 \mathrm{Fg}^{-1}$ at $0.5 \mathrm{Ag}^{-1}$, much higher than that of $\mathrm{MnO}_{2} / \mathrm{MCs}-25\left(245 \mathrm{Fg}^{-1}\right)$ and $\mathrm{MnO}_{2} / \mathrm{MCs}-35\left(155 \mathrm{Fg}^{-1}\right)$. Suggesting that $\mathrm{MnO}_{2} / \mathrm{MCs}-30$ sample is an optimum candidate for supercapacitor electrode application. 


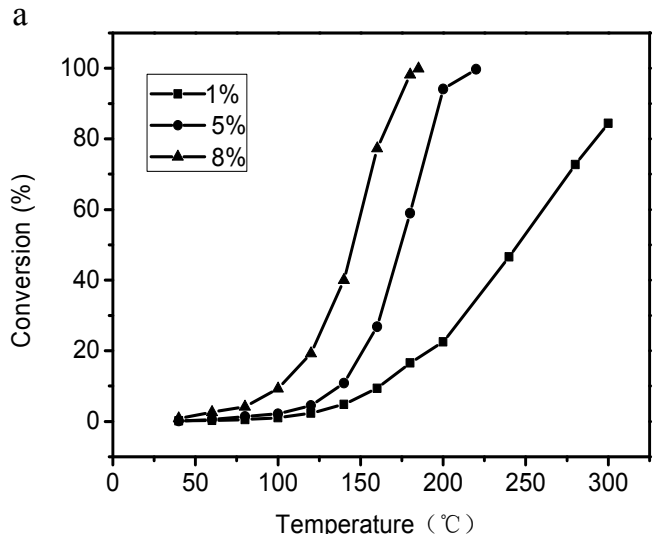

b

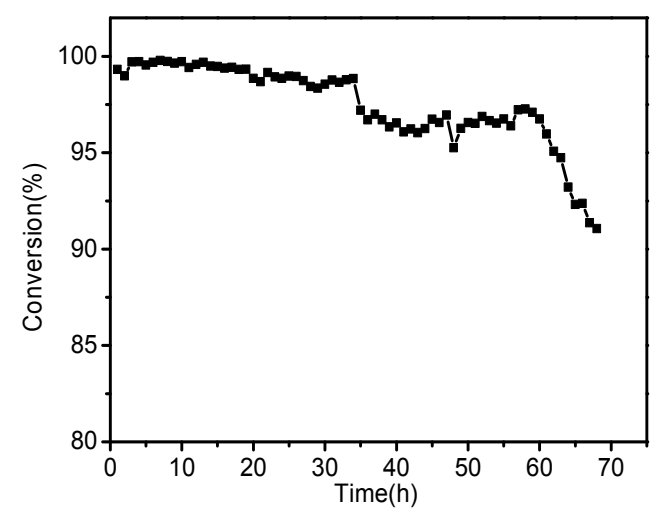

Figure 5.(a) $\mathrm{CO}$ conversion curves of $1 \% \mathrm{Au} / \mathrm{MnO}_{2} / \mathrm{MCs}-46$, $5 \% \mathrm{Au} / \mathrm{MnO}_{2} / \mathrm{MCs}-46, \quad 8 \% \mathrm{Au} / \mathrm{MnO}_{2} / \mathrm{MCs}-46, \quad$ (b) Stability of $8 \% \mathrm{Au} / \mathrm{MnO}_{2} / \mathrm{MCs}-46$ as a function of time on stream.

Futhermore, the $\mathrm{MnO}_{2} / \mathrm{MCs}-45$ was employed as $\mathrm{Au}$ catalyst support for $\mathrm{CO}$ oxidation, and the result are shown in Figure 5. Various $\mathrm{Au}$ amount $(1,5,8 \%)$ was loaded on support, and was tested in a fanction of the temperature. The high loading of $\mathrm{Au}$ NPs have high activity in $\mathrm{CO}$ oxidation. The catalytic stability was tested as shown in Figure 5b. The catalyst had obvious deactivation on stream after $65 \mathrm{~h}$ reaction time at the reaction temperature of $185^{\circ} \mathrm{C}$.

\section{CONCLUSIONS}

$\mathrm{MnO}_{2} / \mathrm{MC}$ spherical composite was prepared by hydrothermal method have good electrochemical performance. The specific capacitance of the $\mathrm{MnO}_{2} / \mathrm{MCs}-$ 30 electrode is $275 \mathrm{Fg}^{-1}$ at $0.5 \mathrm{Ag}^{-1}$ in $6 \mathrm{M} \mathrm{KOH}$ solution. $\mathrm{MnO}_{2} / \mathrm{MCs}$ composite is good for supercapacitor electrode application. $\mathrm{MnO}_{2} / \mathrm{MC}$ spherical composite was used as support of $\mathrm{Au}$ catalyst. The catalyst is active and stable, studying on $\mathrm{CO}$ oxidation. $\mathrm{MnO}_{2} / \mathrm{MC}$ spherical composite promotes the study process in electrochemistry and $\mathrm{CO}$ oxidation.
[1] Liu M, Gan L, Xiong W, et al. Development of $\mathrm{MnO}_{2}$ /porous carbon microspheres with a partially graphitic structure for high performance supercapacitor electrodes[J]. Journal of Materials Chemistry A, 2014, 2(8): 2555-2562.

[2] Li H, Jiang $\mathrm{L}$, Cheng Q, et al. $\mathrm{MnO}_{2}$ nanoflakes/hierarchical porous carbon nanocomposites for high-performance supercapacitor electrodes[J]. Electrochimica Acta, 2015, 164: 252-259.

[3] Liu C, Li F, Ma L P, et al. Advanced materials for energy storage[J]. Advanced Materials, 2010, 22(8): E28-E62.

[4] Wang G, Zhang L, Zhang J. A review of electrode materials for electrochemical supercapacitors[J]. Chemical Society Reviews, 2012, 41(2): 797-828.

[5] Yang Z C, Tang C H, Gong H, et al. Hollow spheres of nanocarbon and their manganese dioxide hybrids derived from soft template for supercapacitor application[J]. Journal of Power Sources, 2013, 240: 713-720

[6] Zhao Y, Meng Y, Jiang P. Carbon $@, \mathrm{MnO}_{2}$ core-shell nanospheres for flexible high-performance supercapacitor electrode materials $[\mathrm{J}]$. Journal of Power Sources, 2014, 259: 219-226.

[7] Yan J, Fan Z, Wei T, et al. Carbon nanotube $/ \mathrm{MnO}_{2}$ composites synthesized by microwave-assisted method for supercapacitors with high power and energy densities[J]. Journal of Power Sources, 2009, 194(2): 1202-1207.

[8] Zhang K, Zhang L L, Zhao X S, et al. Graphene/polyaniline nanofiber composites as supercapacitor electrodes[J]. Chemistry of Materials, 2010, 22(4): 1392-1401.

[9] Yan Y, Cheng Q, Wang G, et al. Growth of polyaniline nanowhiskers on mesoporous carbon for supercapacitor application[J]. Journal of Power Sources, 2011, 196(18): 78357840 .

[10] Zhang H, Cao G, Wang Z, et al. Growth of manganese oxide nanoflowers on vertically-aligned carbon nanotube arrays for highrate electrochemical capacitive energy storage[J]. Nano letters, 2008, 8(9): 2664-2668.

[11] Wang $\mathrm{H}$, Liu J, Wang X, et al. Nanoflaky $\mathrm{MnO}_{2}$ grown in situ on carbon microbeads as an anode material for high-performance lithium-ion batteries[J]. RSC Advances, 2014, 4(42): 22241-22245. 